$3-22-2019$

\title{
Understanding Promise: Impact of state support on Latino high school student habitus
}

\author{
Zarrina Talan Azizova \\ University of North Dakota, zarrina.azizova@und.edu \\ Jesse Perez Mendez
}

\section{How does access to this work benefit you? Let us know!}

Follow this and additional works at: https://commons.und.edu/tl-fac

Part of the Arts and Humanities Commons, and the Educational Leadership Commons

\section{Recommended Citation}

Zarrina Talan Azizova and Jesse Perez Mendez. "Understanding Promise: Impact of state support on Latino high school student habitus" (2019). Teaching \& Learning Faculty Publications. 11.

https://commons.und.edu/tl-fac/11

This Article is brought to you for free and open access by the Department of Teaching and Learning at UND Scholarly Commons. It has been accepted for inclusion in Teaching \& Learning Faculty Publications by an authorized administrator of UND Scholarly Commons. For more information, please contact und.commons@library.und.edu. 


\section{Understanding Promise: Impact of state support on Latino high school student habitus}

\section{Zarrina Talan Azizova \& Jesse Perez Mendez}

To cite this article: Zarrina Talan Azizova \& Jesse Perez Mendez (2019): Understanding Promise: Impact of state support on Latino high school student habitus, Journal of Latinos and Education, DOI: $10.1080 / 15348431.2019 .1590203$

To link to this article: https://doi.org/10.1080/15348431.2019.1590203

曲 Published online: 22 Mar 2019.

Submit your article to this journal $\pi$

Џ Article views: 9

View Crossmark data ¿ 


\title{
Understanding Promise: Impact of state support on Latino high school student habitus
}

\author{
Zarrina Talan Azizova (iD) and Jesse Perez Mendez
}

\begin{abstract}
This study examined the role of a state need-based financial aid policy in Latina/o high school students' meaning making of postsecondary access. Utilizing narrative research, the analytical focus on the meaning making uncovered patterns of individual agency in the journeys of eight Latina/o high school students who were recent enrollees in the state need-based financial aid program.
\end{abstract}

\section{ARTICLE HISTORY}

Received 15 Feb 2017 Accepted 01 Mar 2019 Revised 28 Nov 2018

\section{KEYWORDS}

College aspirations and expectations; need-based financial aid policy; academic capital formation; habitus; narrative research

According to the Pew Research Center, the Latina/o population is the youngest compared to other racial/ ethnic groups (Patten, 2016) and continues to enjoy national growth compared to all other populations in public K-12 schools, increasing from $16.7 \%$ in 2000 to $19.9 \%$ in 2004 , and to nearly $25 \%$ nationwide in 2012 (Fry \& Lopez, 2012). This trend remains in effect in the foreseeable future (Excelencia in Education, 2015). Another report indicates that $66.1 \%$ of Hispanic parents and $47.9 \%$ from low-income backgrounds support their children's desire to pursue a bachelor's degree (Child Trends Databank, 2015). A study by the Pew Research Center (2009) also revealed that college aspirations are high in Latina/o families, reporting that $77 \%$ of Latino parents believe that their children should go to college. However, only $48 \%$ of young Latinas/os expect to pursue college education. This dynamic between college aspirational capital and college expectations highlights the need for examining college pathways for Latina/o children (Espinosa, Gartner, \& Orfield, 2015). The literature has been documenting disparities in educational opportunities and constraints stemming from structural/social/economic contexts where financial hardship has been a central concern (Crawford \& Arnold, 2016; Dabach, Suárez-Orozco, Hernandez \& Brooks, 2017; Gonzales, 2012, 2015; Milner, 2013; Nuñez, 2009; Tienda, 2006). The underlying premise of these studies is that Latina/o children's college decisions are products of structural/economic determinism, which limits a possibility of recognizing an individual agency in college decisions within (constraining) structural and economic conditions. Such emphasis maintains a deficit view on college access of Latina/o youth.

To take an anti-deficit perspective and to understand the interplay between college aspirations and college expectations, researchers need to shift from a macro- to a micro-level of data collection and analysis. Research needs to focus on ways Latina/o children interpret their realities and (re)shape meanings of their college prospects. The (re)shaping of meanings of individual college prospects assumes a dialectic view of habitus. For this reason, we utilize Bourdieu's definition of habitus where it is a "learned set of preferences or dispositions" that are "adaptive and incrementally modifiable in the face of variant circumstances" (Edgerton \& Roberts, 2014, p. 199), which is later revisited in more detail in the theoretical framework of this article. Adaptation and modification of one's habitus entail meaningmaking processes, experiences and, potentially, a shift under changing circumstances.

Thus, the purpose of this narrative study was to understand meaning making about college prospects of low-income Latina/o high school students who were enrollees in a state need-based college access program (Oklahoma's Promise). Primary areas of interest were college expectations 
and academic capital formation of these students and the role of Oklahoma's Promise in their meanings of college education and opportunity (Campbell, 2003; Cornwell \& Mustard, 2002; Hilberg, Joshi, \& House, 2009; St John, Musoba, \& Simmons, 2003). Two research questions guided this inquiry:

(1) Who are the most influential agents assisting Latino high school students' acquisition and use of information about Oklahoma's Promise?

(2) What role does a state need-based financial aid policy play in Latino high school students' meaning making of postsecondary access (i.e., habitus) and academic capital formation?

\title{
Literature review
}

Edgerton and Roberts's (2014) definition of Bourdieu's habitus serves as a starting point of the literature review because their observation of habitus provides a critical point that the research focus on individuals cannot ignore contextual realities in which their habitus is being shaped and shaping:

\begin{abstract}
Habitus is rooted in family upbringing (socialization within the family) and conditioned by one's position in the social structure. Bourdieu termed it "socialized subjectivity" or subjectivity conditioned by structural circumstances. Habitus shapes the parameters of people's sense of agency and possibility; it entails perceptual schemes of which ends and means are reasonable given that individual's particular position in a stratified society. (p. 195)
\end{abstract}

Thus, this review of the literature covers critical research that has been examining structural/cultural and economic conditions that affect college access and college success of low-income and racial/ ethnic students.

Although, as the literature suggests, racial/ethnic low-income students aspire to college education, but they tend to perceive a college or university degree as something unattainable (Bohon, Johnson, \& Gorman, 2006; Kao \& Tienda, 1998). Compared with other racial/ethnic groups, Latina/o high school students fulfill their college aspirations at a lower rate (Martinez \& Cervera, 2012). Other literature and reports highlight that Latina/o students are significantly underrepresented in four-year institutions (Harvey \& Anderson, 2005; St. John, 2002; St. John \& Musoba, 2011; U.S. Census, 2014). Scholars find that college costs, access to information about financial aid policies at state or institutional levels, exposure to social networks, sense of belonging to college culture, academic selfesteem, and encouragement of their families are the factors affecting Latina/o students' college decisions (Brown \& Lopez, 2013; Cabrera \& La Nasa, 2000a; 2000b, 2000c; Gonzalez, 2015; Kurlaender, 2006; Nora, 2004; Paulsen \& St. John, 2002; Perez \& McDonough, 2008; Perna, 2000, 2006; St. John, Daun-Barnett, \& Moronski-Chapman, 2013; Valdez, 2008). The emphasis on financial factors is the strongest in the literature, which we highlight in this review to address financial realities as a context in which social capital and habitus emerge as factors in college-going decisions.

Financial capital and cultural tendencies of Latina/o students play an integral role in their collegegoing trends. St. John (2006) explained, "finances play a role in the acquisition of cultural capital, but it is [sic] filtered through cultural experiences" (p. 161). More recent research finds that the lack of financial capital in itself is not the crux of the access gap among Latina/o groups, but the perceptions of costs inhibit college access (Sanchez, Usinger, \& Thornton, 2015). Kurlaender's (2006) study further adds that even higher-SES and high-academic-ability Latina/o students are more likely to select community colleges compared to other racial/ethnic groups with similar SES and academic backgrounds. Perna (2006) explained this phenomenon, suggesting a four-layer contextual complexity of student college enrollment behaviors. Individual dispositions towards college, as Perna (2006) observed, are shaped by a broader (1) socio-economic and policy context; (2) higher education context; (3) school and community context; and (4) habitus. Each layer influences the next one in an inward direction, where habitus becomes a final product of the other three. Each layer depicts policies and factors that contribute to differences across racial/ethnic groups in their understanding of college costs 
and enrollment information. Latina/o families and students' unwillingness to rely on loans to finance college education remains one of the examples of this habitual dynamic (Perna, 2000, 2006).

Taking the concept of habitus in a different direction, Nora (2004) conceptualized habitus and cultural capital as psychosocial factors to find and validate their strong influence on Latino college decisions to attend selective or non-selective higher education institutions. These factors included perceptions on personal acceptance, pre-college experiences (including campus visits), sense of match between academic interests and an institution, extra-familial encouragement, personal and social fit, institutional support, and pre-college influences including family encouragement. Nora (2004) recommended that involving pre-high school students in university and college campus events might help students develop favorable psychological dispositions towards colleges and universities and build social capital necessary for an informed college enrollment decision. After interviewing 106 Latino high school junior and senior students, Perez and McDonough (2008) found that family, friends, and school personnel were influential information carriers for these students, whereas extended family members who had first-hand college experience were the most trusted source of information. They concluded that exposure to "high levels of social capital" through "access to more and varied resources" was not readily available to these students and argued that more collaborative outreach models would benefit this group (p. 13). While family members and friends are frequent information sources for other racial/ethnic minorities (Martinez, Cortez, \& Saenz, 2013), Latina/o high school students were least likely to use college resources in Martinez and Cervera's (2012) study of a nationally representative sample of high school students. As a result, Latina/o students, who aspired to a college degree from four-year institutions, did not make any college applications by spring of their senior year. Students remained underinformed about all possible college prospects within such networks. In unison with Perez and McDonough's (2008) recommendations, Martinez and Cervera (2012) argued that "the mobilization of institutional resources," including college as well as high school agents, should be an intentional and purposeful strategy assisting Latina/o students' formation of social capital towards higher education access (p. 391). Regarding high school resources, participants in another study expected school personnel and teachers in particular to assume most of the responsibility for creating a "pro-college culture" for these students (Castillo, Conoley, Cepeda, Ivy, \& Archuleta, 2010). For example, the role of teachers was profound in cultivating "resistance and aspirational capital" for Mexican American students from the South Texas Border to confront negative stereotypes about Latinos (Martinez, 2012, p. 76).

Enrollment in financial aid programs, together with exposure to other school resources, can be a powerful step in a formation of social and academic capital towards higher education access (Castillo et al., 2010; Martinez \& Cervera, 2012; Perez \& McDonough, 2008). At the system level, schools, promoting personalized relationships between students and staff to communicate academic norms and point to valuable information resources, contributed to students' college aspirations and strengthened their college planning (Holland \& Farmer-Hinton, 2009). The researchers of these studies suggested that further research might need to examine the interactions between Latina/o high school students and various institutional agents with a specific focus on a student level in these interactions.

\section{Conceptual framework}

We focused on students' interpretative practice of their experiences as an enrollee in the state needbased financial program and their actions towards the goal of attending postsecondary institutions. Within this analytical focus on individual meaning making, the recognition of a socio-cultural and economic context was essential. In other words, the low-income high school student's meaningmaking act occurred not in a vacuum, but was influenced and, in some instances, constrained by social, cultural, and financial factors. We utilized St. John, Hu, and Fisher's (2011) work on academic capital formation (ACF) because of the scholars' specific application of cultural capital concepts in their research on the issues of college access. Building on the theories of Gary Becker, James Coleman, and Pierre Bourdieu, St. John et al. (2011) outlined six constructs of ACF (concerns 
about costs, networking, trust, information, cultural capital, and habitual patterns) to examine college access barriers. The scholars targeted structural, social, and cultural arrangements to explain impediments to college access of low-income first-generation students. According to their conceptualization, the macro-focus and emphasis on structural and social/cultural intervention programs play a central role in enabling and stimulating ACF social processes. A state need-based financial aid program is one of such interventions, which serves as the contextual imperative in our study of individual students and their agency.

Central conceptual orientation in our study stemmed from St. John et al.'s explicit theoretical assumption that academic capital, like social capital, should be viewed not as an entity, but rather as a process and functionality leading to a possibility of change in life trajectories of individuals, in which habitus is internal and instrumental (St. John et al., 2011). St. John et al. (2011) stated, "Habitus refers to recurring behaviors or sequences of strategic moves patterned through culturally transmitted habit rather than intention" (p. 40). However, we considered not only culturally transmitted habitual behaviors, but also possibilities of the impact of aid policies on an individual student intentional act towards college access and degree attainment. Blending objective structuralist assumptions and a subjective non-rational view of the role of individuals, Bourdieu developed the concept of habitus to suggest that an individual is a product as well as a changing force of social structures/fields. With that analytical focus (i.e., habitus as an active cognitive behavior), we realized a possibility of human agency in ACF processes, stemming from a meaning-making act of underrepresented college populations who participated in a college access program. Edgerton and Roberts (2014) further clarified that researchers should not separate Bourdieu's habitus and cultural capital concepts in research on inequities. Rather, their treatment of a "coupled nature of habitus and capital" provided insight into the "mechanism" of capital formation (p. 209). Specifically, they suggested that "...dispositions of the habitus generate practices in fields which in turn can affect those dispositions by (de)valuing them as cultural capital” (p. 209).

Influenced by a point of view (determined by the presence of structure in the form of economic and cultural capital), an individual's habitus is a product of internalization of externality processes within social structures (Bourdieu, 1977). Bourdieu further noted, "the field, as a structured space, tends to structure the habitus, while the habitus tends to structure the perceptions of the field" (Bourdieu, 1988, p. 784). Earlier in his work, Bourdieu (1977) questioned intentionality and reflexivity of an individual act contemplating that "meanings and consequences of action are not transparent to the actors themselves" (p. 72). However, as Everett (2002) observed of Bourdieu's later works:

[Bourdieu] appears as convinced that social agents are not objects guided by rules or codes... he is clear that the social agent pursues strategies, that social agents do weigh their "interests" prior to any action. It is just that these strategies are always in some way constrained. Habitus in this sense is Bourdieu's attempt to overturn, or at least reconcile, the subject-object duality. (p. 66)

To reconcile the subject-object duality in qualitative research, Gubrium and Holstein (1997) called for a reasoning that "de-privileges" the logical separation between subjects and structures/context, calling for a recognition of individual meaning-making acts within a historical and cultural context (Author, 2016). Such structural constructionism is evident in Bourdieu's explanation of habitus in connection with fields. Fields are relational meaning-making social arenas (Everett, 2002).

In the absence of support programs, fields may imply social and cultural reproduction where class habitus negates the possibilities of social and cultural uplift (St. John et al., 2011). However, fields can be seen as an opportunity arena once its substantive conditions change through, for example, one's enrollment and participation in the state need-based aid program and attendance at a charter school with a STEAM curriculum emphasis. Upon entering such an opportunity arena, an individual gets relocated to a different point of view (Bourdieu, 1988), where the chance presents itself for an individual to act in new ways or, in other words, to "re-author" his or her habitus (Drummond, 1998, p. 97). Drummond (1998) discerned such agentic qualities of habitus in his narrative research of organizations in connections to conflict (imposition and resistance of habitus) and change 
(disruption and replacement of habitus). To affirm such a possibility of habitus, Everett (2002) pointed out, "Bourdieu's work does not rule out agency, consciousness, or change" (p. 76). Thus, fields with the enhanced opportunity and provisions for college access may open up a possibility for a low-income high school student to assume an active self-empowering role to re-author habitus towards specific ends of capital formation. This individual meaning-making act/re-authoring was the analytical focus in our research.

\section{Methods}

Applying Bourdieu's habitus in his narrative research, Drummond (1998) proposed that habitus is made of narratives, "which are themselves structured and structuring action" (p. 105). Analysis of construction of organizational or, in our case, individual narratives offers potential to discern meanings that shape habitus of low-income Latina/o high school students in the fields of college access. We followed Holstein and Gubrium $(1998,2000)$ data collection and analytical techniques in narrative research. Data collection required an open-ended dialogical interview, where the researchers' role was to activate the participants' story-telling. The interview protocol was, thus, semistructured with an open possibility of follow-up questions. Inherent in Gubrium and Holstein's data analysis is the recognition that social/cultural structure cannot be separate from the act of production of individual narratives/meanings, which corresponds closely with the conceptual assumption of habitus (Gubrium \& Holstein, 2001, 2009). Thus, our research design relied on narrative practice as an individual's meaning-making act and "the everyday technology" of habitus construction/agency within a broader structural/social/economic domain that undermined college opportunities for these individuals (Holstein \& Gubrium, 2000, p. 103).

\section{Site and participant selection}

We interviewed eight individuals with the attributes specific to the focus of the study (Berg, 2004; Gubrium \& Holstein, 1997). All study participants were low-income, Latina/o high school students who were enrolled in Oklahoma's Promise, the state need-based grant program. Created by the Oklahoma legislature in 1992 and administrated by the Oklahoma State Regents for Higher Education (OSRHE), Oklahoma's Promise pays for the college tuition of participants if they achieve particular benchmarks. Its original title, Oklahoma Higher Learning Access Program, conveys the essence of this program: a financial need-conscious college access opportunity. To be eligible, first, students must demonstrate that their family income is less than $\$ 55,000$ a year and meet specific high school academic requirements. Students apply for program participation in the eighth, ninth, or tenth grade. Once admitted into the program, participants must complete a 17-unit college preparatory curriculum before high school graduation. Second, program participants must avoid a criminal record, provide relevant academic information to various state agencies such as the State Board of Education, and participate in volunteering activities. As they approach their high school completion point, program enrollees are encouraged to pursue other forms of financial assistance, satisfy requirements for state residency, and earn an overall high school GPA of 2.5 or higher by graduation (OK SB 820, 2009).

We selected our participants from an urban charter school of Oklahoma because this school enrolled (1) a high percentage of Latino/a students, (2) a high percentage of students participating in the Oklahoma's Promise program, and (3) a high percentage of Latino/a students on a college preparatory track. Throughout its history, the mission of the school emphasized a nurturing and supportive educational environment tailored to the academic needs and talents of their students. With the assistance of the school officials, the call for research participation was distributed through both student and parent email listserves. Additionally, students were given hard copies of the flyer, the parental assent form, and the participant consent form to take home and given time to decide whether or not they wanted to participate in this study. 


\section{Data collection and analysis}

This study adhered strictly to the ethics and principles of the responsible research conduct with minors since our participants were between 16 and 18 years old. Before receiving the approval of the Institutional Review Board (IRB), we completed university-mandated training on how to conduct research on minors. Upon IRB approval, we began our recruitment efforts by approaching the school counselors with the request to forward our written call for research participation to students and their parents. Students were able to review the consent form and take home the parent/guardian assent form. Only after receiving preliminary agreement from both parents and students were we able to proceed with scheduling the interviews. At the beginning of each interview, we reviewed the purpose of this research and participants' confidentiality rights together with parents and students and asked them to sign the adult assent and participant consent forms at the end of this review.

All interviews took place on the premises of the school. The mothers of seven out of eight participants chose to stay with their children during the interviews, which unintentionally provided a triangulation layer to the interview data (Maxwell, 2005). Parents either affirmed their children's information during the interview or added some clarifications when their children mentioned the role of their parents/families in their college aspirations and expectations.

We employed a semi-structured protocol with an open possibility of follow-up questions (Gubrium \& Holstein, 1997, 2003; Kvale, 1996) for the face-to-face interviews with the participants. We designed questions to probe meaning making of the participants (i.e., the whats and hows of their paths to higher education) and the role of Oklahoma's Promise and other structural and economic conditions in shaping their meanings of college access (Appendix A). The interviews ranged from 35 to 45 minutes, with both authors conducting the interviews with each participant. All interviews were audiotaped and transcribed immediately. The participants selected pseudonames to replace their real names.

Data analysis became a two-stage process. In the initial stage, we applied narrative linkages (Holstein \& Gubrium, 2000; Poindexter, 2002, 2003) to construct an individual narrative and uncover meanings of roles of families, teachers, and participation in Oklahoma's Promise as they emerged in a dialogue between the researchers and the participant (Poindexter, 2003). During this stage, each author completed this analytical task independent of the other. We then compared and contrasted our findings and merged them into a single narrative/story for each participant. We concluded this stage by assigning a title to each narrative to convey the essence of that individual participant's meaning making or story (Table 1). In the next stage, we began our review of all narratives with the aim to foreground similarities and differences across the stories and to look for converging trends of participants' meaning-making/active role (Riessman \& Quinney, 2005). During that stage, we followed Labov's narrative construction model (Coffey \& Atkinson, 1996). This model included the following narrative structure units: abstract (what was this about?), orientation (who? what? when? where?), complication (then what happened?), evaluation (so what?), result (what finally happened?), and coda (finished narrative) (Coffey \& Atkinson, 1996, p. 58). The application of these action-oriented units helped us to maintain our analytical focus on lowincome Latino/a high school students' agency or, in other words, re-authored habitus within the context of various events, life situations, and educational opportunities. We addressed potential researchers' biases through researchers' reflexivity and member check techniques (LeCompte \& Preissle, 2003; Luttrell, 2010; Maxwell, 2005).

\section{Limitations}

We saw two limitations in this study, which we would like to address in this section. First, the parents' decision to stay with their children during the interviews was an unexpected voluntary choice of the parents and the participants. The participants came to the interview with their parents in the first place, although they had an option of just bringing a signed parent assent form to the interview. Such a turn in the research design could be considered a limitation from the traditional 





perspective on social research. This perspective echoes some scholarly assertions that "there is a new demand for research that focuses on children as actors in their own right" (for example, see Christensen \& James, 2008, p. 87) and children should be guaranteed confidentiality and privacy rights similar to those to which adult research participants are entitled (Morrow \& Richards, 1996). These arguments about ethics of social research with children usually stem from the problematization of "legal notions" of children being "vulnerable" and "incompetent" (Morrow \& Richards, 2008, p. 98). We certainly saw some merit in these assertions that children should not be seen as "powerless" (Morrow \& Richards, 2008, p. 98) actors of their realities and, thus, should have their chance to narrate their responses without the presence of their parents. However, following the premise of a culturally sensitive research (Tillman, 2002) was our counterargument to this limitation in our study and stood as the position of ethics in itself, meaning that placing unique cultural nuances of the research participants at the center of the design and inquiry was more critical. In this case, we recognized parents' choice to remain in the room as a form of their moral support for all school-related activities of their children, which is the integral part of Latino immigrant family structure and culture (Auerbach, 2006, p. 277). Research has documented that Latino youth draw support and strength from their families and, thus, separation from their families is a somewhat unnatural move in research and practice.

Second, from a pragmatic point of view, the other limitation of this study stems from the fact that this study was not longitudinal in its design, where tracking participants' actual college-going trajectory would be possible to see whether they ended up applying to and enrolling in a college of their choice. We concluded all interactions with the participants and the school at the end of the data analysis (i.e., approximately three months after the one-time face-to-face individual interviews and the school visit). While, based on the thoughts and plans that the participants shared with us, we could reasonably conclude that the program participation did make the participants more likely to apply to and enroll in college, we could not claim this outcome with an empirical certainty. However, it is worth noting that the purpose of the study was not to examine the effect of Oklahoma's Promise on actual college enrollment, but to understand the participants' thought processes (i.e., cognitive schemata of habitus) regarding their college prospects under the circumstances of their participation in the college access program.

\section{Findings}

After the first stage of data analysis was complete, eight narrative portraits emerged for the participants (Table 1). Each narrative foregrounded each participant's meanings of a college degree value, role of families, school teachers/counselors, and peers, as well as meanings of the impact of Oklahoma's Promise on their college aspirations and expectations to build their path to college. The second stage of the data analysis took a comparative approach to all of the narratives through the theoretical lens of habitus as a form of individual agency. This round revealed five converging trends of individual meanings: having more opportunities and a better life, feeling and perceiving financial matters, visualizing college experience, navigating other forms of support, and growing qualities of individual agency.

\section{Having more opportunities and a better life}

Parents of the participants did not hold college degrees, some were high school dropouts, and most possessed limited English proficiency. All of the participants indicated that a college degree was an opportunity for a better life that their parents did not have. According to them, their parents' socioeconomic standing and constant reinforcement of the value of a college degree were the important elements contributing to the participants' college aspirations. Messi shared that "I want to go to college 'cause I want to get ahead of life and kind of help my parents cause they helped me a lot too." Lily valued college degree as a signifier of social status, stating that "I usually look up to people who have gone to college, I respect them, and I think it is probably something that is required 
nowadays." Cesar emphasized the role of this parents as well, as they encouraged his interest in colleges and universities, "They always told me to live the American dream-so they came in here for me to have the best-they say go to college." Fernando offered a similar valuation of a college degree as a means to a socioeconomic uplift:

I help [his father] with his business. So it's kind of teaching me how life would be if you don't go to college. Because I see a lot of, I hear a lot of my friends from middle school, how they dropped out of high school already and they are already working. And I don't want that. My dad notices that I don't want to do that. He's like "look at what you are doing right now, if you don't go on to college or university, get a major, this is what your future will be like." Construction, basically.

However, unlike the other participants, Fernando developed his reflections about a college degree through his observations and increased awareness of a broader critical context that typically conditions possibilities for an individual's socioeconomic breakthrough:

[A college degree] is something really important, I mean, some people leave high school and go on to work, but I have seen it happen several times. They move on to work field, but they don't have the mentality of progressing to going on to college. You have to keep on growing and be better than society expects you to after you leave high school. So, I think that it is something really important in my mind. I have been told by my parents a lot that you should expect to grow, not to stay how society thinks you should stay.

Jackie associated a college degree specifically with "the more opportunities to get a job and to have like a better life."

\section{Feeling and perceiving financial matters}

The families' modest socioeconomic background served as a meaning-making platform to perceive finances as the strongest barrier to college education. All of the participants expressed strong emotions about funding of their college education. Cesar summarized his perspective, suggesting that the "[s]cariest [thing about college] [is] probably the payment; I've heard a lot of stories about people getting in lot of debt they couldn't pay." Not surprisingly, all of the participants acknowledged that being enrolled in Oklahoma's Promise not only granted them a sense of relief, but also helped them realize their role of translating their college aspirations into a reality. Jackie offered that "[Oklahoma's Promise] gives an opportunity or hope for those who are in need of money to go to college" and Scarlet expressed her view that "[Oklahoma's Promise] does give me a lot of confidence like cause you have a little sense of security in you as you start approaching that time." She further clarified that going to college "seems more realistic" since she enrolled in the program.

As a result of the family influence and promise of the financial aid, the participants extended their meanings from college aspirations to actual college expectations. The participants' narratives in our study reflected increased college expectations as they approached their junior and senior years, citing two driving factors: (1) a prospect of living "a better life" than their parents had (including a prospect of helping out their parents upon completion of their college education); and (2) a sense of financial security granted by Oklahoma's Promise. Both of these reasons, closely connected, seemed to strengthen the participants' beliefs that college was not a mere aspiration for a better life, but a goal that they could work on while "keeping focus," "studying harder," "learning some options," "getting ACT scores up," "asking for help of teachers and counselors," and "looking for additional scholarships."

\section{Visualizing college experience}

While the meanings of the academic side of college access were the products of the participants' interactions with parents and school personnel, images of college life seemed to emerge from different sources, such as movies, social media, or interactions with peers. All of the participants shared a univocal image of collegiate life, associating college with "smart people," "big classrooms," "a lot of students," "a lot of responsibility," "lots of studying and lots of testing," "the volume of work they give you," "library and 
classrooms," and "also profession." In their views, academic difficulties and regimented lifestyles seemed to be necessary qualities of college life. Cesar projected the following vision:

Like lot of studying, lot of work, scholarships, and like going to new world, going to adult life.... You sleep at a campus, right? In a housing or something like an apartment.... You know like waking up, going to study, going to classes, coming back and studying. Till like that you can't be prepared, you know, putting your everything.

$\mathrm{Al}$ shared that "I heard many stories that colleges are a lot harder than high schools," and explained that it made him nervous that he "wouldn't be able to pass this class, this assignment, this essay." Fernando offered an image of a "living on your own" student, clarifying that "I get a feeling that you go to class, to your dorm, but basically you are on your own, you have to be responsible for yourself there." His mother contributed her comment during our conversation with her son, expressing her vision of an inherently difficult academic culture: "I told him when you will be in college, you are gonna suffer a lot, you need to memorize." Messi made an interesting comparison between projections of college in pop culture and his actual thoughts on what it might look like:

\begin{abstract}
When someone tells me "college or university, what do you think?" I think sleeping in late, homework and party. That is what I think probably because of all the movies I watched. Comedy, they always do that... like kid goes to college, he goes to class and then at night he goes to a fraternity or sorority and just party... just everything goes crazy [laughs]. I mean that's not what actually is, I mean, sometimes might be. But, you know, its more like buckle down and listen to lectures for like three hours and then go home and read like six chapters and then take a test and then just hope for the best.
\end{abstract}

Vanessa's and Scarlet's concerns of "not being able to keep up with classes and to study" and "being on my own" signified a common-to-all emotional response, such as anxiety, nervousness, and even fear, connected to what the participants described as a college culture. "It's a little scary because it is different," Scarlet concluded her thoughts about going to college and living on campus. Despite such emotional responses to what they believed to be difficult, all of the participants were certain that they could cope with a demanding college life by relying on their social support systems outside of college and building their agency.

\title{
Navigating other forms of support
}

The participants suggested that virtual peer communities in social media, older siblings, or extended family members were pillars of their social support, in addition to parents and high school teachers and counselors. As our research focus switched from the structural focus to a dispositional focus with the emphasis on high school student agency behind the social support phenomenon, we began seeing how the participants tended to choose and lean purposefully towards specific sources of support that they perceived as potentially more helpful and encouraging. One the one hand, the majority of the participants indicated that their parents (mostly mothers) pushed them to enroll in Oklahoma's Promise or completed paperwork themselves for their children, even though these parents did not have a college education and had limited English proficiency. These parents set an example of individual agency-a purposeful action of navigating college-going opportunities. Cesar made that point particularly clear:

Oklahoma's Promise... I always saw it as a scholarship, you know, I've been getting a lot of information about it, but when my parents told me about that, I looked forward to it, you know. I was going to look at scholarships and Oklahoma Promise the one that I had to enroll. I think I got to it when I was freshman. Is that right? [asking his mother who sat next to him during the interview]... Yes, my parents shared about that and they said "you know, you apply for it."

On the other hand, the participants also tended to defer to their teachers or school counselors when they needed social support and words of encouragement, in addition to any specific advice related to the structural navigation on their path to college education. Referring to his high school teachers, Fernando stated, "They want you to do good in high school so you can move into college." Lily 
shared that she was relying on the words of encouragement and advice from her Latin teacher, "Besides [Latin teacher] and [immediate family members], there is no one else."

\section{Growing qualities of individual agency}

All eight narratives revealed a striking sense of individual self regarding the internal forces driving their actions towards college education. For example, Fernando clarified that his self-determination was an important element of his path to a college education:

I wouldn't say that we are financially bad, but we are not financially able to support me to go to college. I do want to work hard so I can obtain scholarships.... And if I got off [academic] track, that would be an [additional] obstacle, but I'm willing to work hard not to get off track.

Messi described his personal initiatives, such as organizing visits to the college campuses of the major state flagship universities, "I am organizing and I am asking for college days so that I can go visiting cause I know what OSU-OKC [a branch campus of the Oklahoma State University system] looks like, but I want to see what's the real, big one looks like." He further added, "To have a college degree is like a lot of time and effort you put into it and I think it is very valuable." He also shared his perception of the impact of Oklahoma's Promise on his personal development:

I feel like [Oklahoma's Promise] says it pays for tuition, but I also think by telling you stay out of trouble and keep your grades up, it is kind of pushing you towards to being a better person overall.... I feel like it helps like with your personality... getting on a better path.

By enrolling in Oklahoma's Promise, Jackie's college choice process became more informed and more ambitious. She emphasized that:

[Enrolling in Oklahoma's Promise] changed like a lot, like I want to go to like the best from the U.S. that suits

my occupation... and I guess like it seems to me more important to get like a better college.

To sustain the promise of a college-going opportunity, Scarlet described pushing herself outside of her comfort zone "to improve skills like learning how to talk to people" because she saw those skills as the important prerequisite to college success. She actively sought for "volunteering in different places." All in all, the participants' sense of self or qualities of habitus were characterized by hope, confidence, belief in oneself, persistence, self-awareness in terms of developmental needs to advance oneself toward college admission, understanding of a college choice, sense of personal responsibility enabled by the sense of financial security (i.e., fulfilling Oklahoma's Promise program requirements), and determination to a socioeconomic uplift.

\section{Discussions and implications}

The interrelatedness of low-income and Latino background reveals a particularly critical pattern associated with college access and underrepresentation in four-year institutions (Harvey \& Anderson, 2005; Paulsen \& St. John, 2002; St. John et al., 2013; St. John \& Musoba, 2011). As the literature points out (McDonough, Antonio, \& Horvat, 1997; Nora, 2004), habitus and cultural capital determine students' college-going decisions, college choice, and academic preparedness, as well as social readiness for college. Other statistical trends (Harvey \& Anderson, 2005; St. John, 2002; St. John \& Musoba, 2011; U.S. Census, 2014) reveal that academically qualified Latino students tend to choose less- or non-selective institutions, which could be explained by the influence of an already established habitus and lack of cultural capital. The literature also points out the other areas of concern about the significantly higher rates of low-income Latino students who do not possess "college-ready" characteristics (Roderick, Nagaoka, \& Coca, 2009).

While Nora (2004) treated habitus and cultural capital constructs as the independent variables on college-going decisions, we looked at habitus as a product shaped by a combination of the following 
meaning-making experiences of our participants: their enrollment in the college access financial program, interactions with schoolteachers, life in a lower socioeconomic status, and relationships with their families (where parents did not hold a college degree, and some were even high school dropouts). The participants in our study presented a unique perspective on how they were shaping a college-oriented habitus under the game-changing circumstances, which, in turn, answered our research questions.

\section{Who are the most influential agents in students' acquisition and use of information?}

Families' lower socioeconomic background did not stand as a detriment, but rather a strong driving motivational force in the participants' college aspirations. Ceja (2004) reported a profound role of parents in sustaining college aspirations, which in turn contributed to the development of educational resiliency in their children. Parents' role in Ceja's study revolved around a narrative construction in homes about the importance of higher education and encouragement. Similarly, families of our participants were their meaning-making platform towards a possibility of an improved economic lifestyle through higher education. Describing their lower-income realities and sharing their understanding of their parents' paths, students depicted their closeness with their families. Holloway, Park, Jones, Bempecat, and Li (2014) examined how Latinos perceived their parents' consejos and the impact it had on their college journey, "[W]hen parents and children experienced a sense of dyadic closeness, parents were able to formulate more specific and detailed advice" (p. 272). Such family advice may take various forms and translate into action.

Syed, Azmitia, and Cooper (2011) found that, while families help their children build academic aspirations, teachers provide the structural guidance necessary for a path to college. However, our participants' parents did not hold that strict distinction. We learned from the narratives that there was an additional phenomenon, such as parental agency in ways parents participated together with their children in the process of navigating college opportunities and translating college aspirations into expectations. Although we did not interview parents in this study to understand their reasoning behind their support actions, some literature suggests that Latino parents try to compensate for real or perceived gaps in support systems in schools (Authors, 2017; Martinez et al., 2013).

\section{What role does a state need-based college access policy play in ACF?}

The role of Oklahoma's Promise was profound in the participants' shift from seeing college as something unreal to concentrating on their potential for pursuing higher education. In their study of the GEAR UP project, Sanchez et al. (2015) report that negative perceptions of college affordability were a detriment to the formation of college enrollment aspirations of Latino students, even though these students could access scholarships and other state and federal aid programs. Bohon et al. (2006) and Cheng and Starks (2002) noted a particularly critical difference between educational expectations and educational aspirations across racial/ethnic minority groups, suggesting that while college aspirations are a somewhat abstract concept that embraces sense of hopefulness, college expectations go beyond that notion to include a realistic self-assessment of what should be done to fulfill that aspiration. While racial/ethnic minority group parents and their children hold higher college aspirations compared to their White counterparts, their college expectations may diminish by junior and senior years with the realization of economic constraints (Martinez \& Cervera, 2012). Being enrolled in a tuition-assistance program such as Oklahoma's Promise granted our participants some sense of financial security. That sense, in turn, shifted their focus to self. That sense meant personal agency in the development of academic potential and readiness for college, as well as the formation of college-going capital. Our participants made it clear that a college degree was not only their aspiration, but also their expectation. As such, the participants maintained a concentrated self-assessment of what they needed to accomplish to build their paths to a college (i.e., tests, grades, skills, college applications, and so forth).

Furthermore, the accumulation of social capital was part of their college expectations. While anticipating a cold and unwelcoming college culture, the participants did not suggest that they would 
be looking for comfort and fit in their college life. Instead, they all talked about their acts of building or navigating their social support systems to be able to cope with their preparations for college and life in college. This sense of individual agency in their perception of college success was strikingly different from what is evident in the literature regarding students' sense of belonging (Cabrera \& La Nasa, 2000a; Nora, 2004; Perez \& McDonough, 2008).

In The Future of Children, Roderick et al. (2009) assert that assisting low-income racial/ethnic students to become college-ready has to be "the central strategy to improve college access and [high school] performance must be to ensure that students leave high school with the academic skills, coursework, and qualifications they need" (p. 188). Roderick et al. place the greatest emphasis on high school reform and school infrastructure, without addressing the strong role of financial aid access programs and policies in a college readiness development. Our participants focused on the necessity of the accumulation of "college-ready" capital, which crystallized out of their experience of being the enrollees of Oklahoma's Promise program. While the participants did acknowledge that their school environment was supportive of their academic development, they noted frequently that enrollment in the Oklahoma's Promise program helped them reduce their sense of anxiety about college costs and, thus, concentrate their perception of themselves as college-going prospects.

\section{Additional questions arise}

While feeling less stressed about the financial matters associated with college access, the participants believed that they had to be working on additional coping strategies to be able to find their social place on campus and to overcome fears and concerns associated with the perception of an "extremely difficult" college life. The personal sense of belonging to a college campus was never assumed nor imagined in the narratives of all the participants, even after accounting for confidence in their academic ability and financial security. In their visions of their college prospects and experiences, the participants were building their sense of personal agency in a manner of $a$ supranormal effort, a concept that Mason (1997) defined and observed among African American and Latino groups. Questioning whether "supra-normal effort is an embedded ethnocultural pattern or merely a response to social and economic discrimination" (p. 38), Mason argued that supra-normal effort, such as higher levels of unobserved attributes and ability, explained the upward mobility and academic achievements of racial/ethnic groups who were raised in poorer households and attended less advantageous educational environments compared to Whites.

We observed that coping with emotions that originated from a state of extreme trepidation about uncertainties and "scary" images of college life reflected an additional psychological effort and ability (i.e., an additional side of habitus) that is typically not taken into consideration in studies on the impact of policies and institutional practices. We argue that this observation of a supra-normal effort in the story-telling of the participants in this study should complicate a traditional sociological rationalization and instrumentalism of habitus and capital in the arena of ACF-oriented college access policies and practices. If habitus is a cognitive process that generates valuable sets of behavior for college access (i.e., college-oriented habitus), where does an acknowledgment of the unobservable psychological and affective dimensions of that cognitive process fall in the ACF practices and policies? Is a supra-normal habitus a valuable capital in association with college-going prospects or is it an unjust burden that the representatives from lower-income Latino groups take upon themselves while translating their college aspirations into expectations and reality?

\section{Recommendations}

Translating the participants' habitus and cultural capital formation into college aspirations and college expectations, we found that the phenomenon appears to be more complex than originally thought from the perspective of academic readiness, social capital, and financial support. While 
driven, academically prepared, and somewhat financially secured, our participants still did not feel an ease about going to college, which warrants a range of recommendations for practice.

First, thinking of ways to foster higher participation rates among low-income families is key, given that we found that participation in Oklahoma's Promise created a mindset shift among our participants from viewing college as unattainable to realizing that a college degree was indeed possible. Although school counselors share information on the financial program with the students in their school, universities and colleges can also play a role in the Oklahoma's Promise program registration. Specifically, higher education recruiters can bring the program registration forms and materials with them when visiting schools or other outreach venues, such as Latino and Black Expos. Moreover, recognizing that parents-namely, mothers in our study-were instrumental in urging their children to pursue higher education and register for Oklahoma's Promise, policymakers and institutions of higher education should reflect on the cultural relevance of their outreach efforts. It may serve institutions of higher education best to hire bilingual recruiting staff and leadership to serve as a conduit to program registration processes and college recruitment that may involve nonEnglish-speaking parents of potential students.

Second, once Oklahoma's Promise students arrive on campus, universities and colleges may also consider educating their own financial aid officers and advisors on the impact of culture on students' perceptions of college life and decision-making processes. Financial aid officers and advisors enjoy face-to-face interaction with first-year students. Thus, these institutional agents have the best vantage point to serve as a critical cultural tie to Oklahoma's Promise Latino students during their most critical year on campus, many of whom may be away from their parents for the first time-the parents who were so instrumental in building their academic cultural capital to begin with.

Finally, other institutional initiatives may center on designing identity-conscious (Pendakur, 2016) workshops on school sites and college campuses to provide realistic insights into the cultural aspects of a college life with the aim to re-focus from the narrative about high-stress and highachievement college cultures to a narrative about friendships and other social and emotional dimensions of college life.

\section{Conclusion}

In conclusion, the purpose of this study was to explore meaning making about college prospects of low-income, Latina/o high school students who were enrolled in a state need-based grant program (Oklahoma's Promise). Early enrollment in a need-based financial program, such as Oklahoma's Promise, undoubtedly contributed to the shaping of a college-oriented habitus and enabled the lowincome Latino high school students to see their college prospects from a different point of view and to take proactive steps towards college education. Although young Latinos are more likely than the general U.S. population to believe in the importance of education, Latino college enrollment remains the lowest when compared to all other racial/ethnic groups (Pew Research Center, 2009). Therefore, it is essential to continue a qualitative line of research to understand which events and experiences may potentially influence and empower college-oriented habitus formation among Latino high school students. Knowledge from this type of research positively contributes to the significance of a need-based college access program and policy development.

\section{Disclosure statement}

No potential conflict of interest was reported by the authors.

\section{ORCID}

Zarrina Talan Azizova (D) http://orcid.org/0000-0001-9237-0970 


\section{References}

Auerbach, S. (2006). "If the student is good, let him fly": Moral support for college among Latino immigrant parents. Journal of Latinos and Education, 5(4), 275-292. doi:10.1207/s1532771xjle0504_4

Berg, B. (2004). Qualitative research methods for the social sciences (5th ed.). Boston: Pearson Publications.

Bohon, S., Johnson, M., \& Gorman, B. (2006). College aspirations and expectations among Latino adolescents in the United States. Social Problems, 53(2), 207-225. doi:10.1525/sp.2006.53.2.207

Bourdieu, P. (1977). Outline of a theory of practice ((R. Nice, Trans.)). Cambridge, UK: Cambridge University Press. Bourdieu, P. (1988). Vive la crese!: For heterodoxy in social science. Theory and Society, 17(5), 773-787. doi:10.1007/ BF00162619

Bourdieu, P. (1990). The logic of practice ((R. Nice, Trans.)). Cambridge: Polity.

Brown, A., \& Lopez, M. H. (2013). Mapping the Latino population, by state, county and city. Washington, DC: Pew Research Center's Hispanic Trends Project.

Cabrera, A. F., \& La Nasa, S. M. (2000a). Understanding the college-choice process. New Directions for Institutional Research, 2000(107), 5-22. doi:10.1002/(ISSN)1536-075X

Cabrera, A. F., \& La Nasa, S. M. (2000b). Overcoming the tasks on the path to college for America's disadvantaged. New Directions for Institutional Research, 2000(107), 31-43. doi:10.1002/(ISSN)1536-075X

Cabrera, A. F., \& La Nasa, S. M. (2000c). Three critical tasks America's disadvantaged face on their path to college. New Directions for Institutional Research, 2000(107), 23-29. doi:10.1002/(ISSN)1536-075X

Campbell, D. (2003). HOPE Springs Eternal. National Crosstalk: A Publication of the National Center for Public Policy and Higher Education, 11(3), 1-4.

Castillo, L., Conoley, C., Cepeda, L., Ivy, K., \& Archuleta, D. (2010). Mexican American adolescents' perceptions of a pro-college culture. Journal of Hispanic Higher Education, 9(1), 61-72. doi:10.1177/1538192709350454

Ceja, M. (2004). Chicana college aspirations and the role of parents: Developing educational resiliency. Journal of Hispanic Higher Education, 3(4), 338-362. doi:10.1177/1538192704268428

Cheng, S., \& Starks, B. (2002). Racial differences in the effects of significant others on students' educational expectations. Sociology of Education, 75(4), 306-327. doi:10.2307/3090281

Child Trends Databank. (2015). Parental expectations for their children's academic attainment. Retrieved from http:// www.childtrends.org/?indicators=parental-expectations-for-their-childrens-academic-attainment

Christensen, P., \& James, A. (Eds.). (2008). Research with children. London: Routledge.

Coffey, A., \& Atkinson, P. (1996). Narratives and stories. In A. Coffey \& P. Atkinson (Eds.), Making sense of qualitative data: Complementary research strategies (pp. 54-82). Thousand Oaks, CA: Sage Publications.

Cornwell, C., \& Mustard, D. (2002). Race and the effects of Georgia's HOPE scholarship. Who Should We Help, 57-72.

Drummond, G. (1998). New theorizing about organizations: The emergence of narrative and social theory for management. Current Topics in Management, 3(2), 93-122.

Enersen, D., Servaty-Seib, H., Pistilli, M., \& Koch, A. (2008). Twenty-First Century Scholars, their parents and guardians, and the sites that serve them. Prepared for Lumina Foundation for Education. Lafayette. IN: Purdue University. Retrieved from https://www.purdue.edu/studentsuccess/documents/TfCSPre-CollegeRepor.pdf

Espinosa, L. L., Gartner, M. N., \& Orfield, G. (2015). Race, class, and college access: Achieving diversity in a shifting legal landscape. Washington, DC: American Council on Education.

Excelencia in Education. (2015). The condition of Latinos in education: 2015 Factbook. Washington, D.C.: Author.

Fong, C. J., Krause, J. M., Acee, T. W., \& Weinstein, C. E. (2015). Motivation for staying in college: Differences between LEP (Limited English Proficiency) and Non-LEP hispanic community college students. Journal of Hispanic Higher Education, 15(4), 340-357. doi:10.1177/1538192715607332

Fry, R., \& Lopez, M. H. (2012). Hispanic student enrollments reach new highs in 2011. Washington, D.C: Pew Research Center. Retrieved from file:///Users/je313945/Downloads/Hispanic-Student-Enrollments-Reach-New-Highs-in-2011_FINAL.pdf

Gonzales, L. D. (2012). Stories of success: Latinas redefining cultural capital. Journal of Latinos and Education, 11(2), 124-138. doi:10.1080/15348431.2012.659566

Gonzalez, L. D. (2015). Barriers to college access for Latino/a adolescents: A comparison of theoretical frameworks. Journal of Latinos and Education, 14(4), 320-335. doi:10.1080/15348431.2015.1091315

Gubrium, J. F., \& Holstein, J. A. (1997). The new language of qualitative method. New York, NY: Oxford University Press, Inc.

Gubrium, J. F., \& Holstein, J. A. (Eds..), (2001). Institutional selves: Troubled identities in a postmodern world. New York, NY: Oxford University Press, Inc.

Gubrium, J. F., \& Holstein, J. A. (Eds.). (2003). Postmodern interviewing. Thousand Oaks, CA: Sage Publications, Inc. Gubrium, J. F., \& Holstein, J. A. (2009). Analyzing narrative reality. Thousand Oaks, CA: Sage Publications, Inc.

Harvey, W. B., \& Anderson, E. L. (2005). Minorities in higher education: 2003-2004; Twenty-first Annual Status Report. Washington, DC: American Council on Education.

Hilberg, S., Joshi, A., \& House, A. (2009). Washington State Achievers program: Influence of the scholarship program on low-income college students' achievement and aspirations. Journal of College Student Retention: Research, Theory \& Practice, 10(4), 447-464. doi:10.2190/CS.10.4.c 
Holland, E., \& Farmer-Hinton, R. (2009). Leave no schools behind: The importance of a college culture in urban public high schools. The High School Journal, 92(3), 24-43. doi:10.1353/hsj.0.0019

Holloway, S. D., Park, S., Jones, M., Bempecat, J., \& Li, J. (2014). “My mom tells me I should follow the roles that's why they have these rules": Perceptions of parental advice giving among Mexican-Americans heritage adolescents. Journal of Latinos and Education, 13, 262-277. doi:10.1080/15348431.2014.887468

Holstein, J. A., \& Gubrium, J. F. (1995). The active interview: Qualitative research methods (Vol. 34). Thousand Oaks, CA: Sage Publications, Inc.

Holstein, J. A., \& Gubrium, J. F. (1998). Phenomenology, ethnomethodology, and interpretive practice. In N. Denzin \& Y. Lincoln (Eds.), Strategies of qualitative inquiry (pp. 137-157). Thousand Oaks: Sage Publications, Inc.

Holstein, J. A., \& Gubrium, J. F. (2000). The self we live by: Narrative identity in a postmodern world. New York, NY: Oxford University Press, Inc.

Holstein, J. A., \& Gubrium, J. F. (2008). Handbook of constructionist research. New York, NY: The Guilford Press.

Hussar, W. J., \& Bailey, T. M. (2013). Projections of education statistics to 2021 (NCES 2013-008). Washington, DC: U.S. Department of Education, National Center for Education Statistics, U.S. Government Printing Office.

Kao, G., \& Tienda, M. (1998). Educational aspirations of minority youth. American Journal of Education, 106, 349-384. doi:10.1086/444188

Kurlaender, M. (2006). Choosing community college: Factors affecting Latino college choice. New Directions for Community Colleges, 133, 7-16. doi:10.1002/cc.223

Kvale. (1996). The 1,000-page question. Qualitative Inquiry, 2(3), 275-284. doi:10.1177/107780049600200302

LeCompte, M., \& Preissle, J. (2003). Ethnography and qualitative design in education research (2nd ed.). San Diego, CA: Academic Press.

Lopez, M. H., \& Fry, R. (2013). Among recent high school grads, Hispanic college enrollment rate surpasses that of Whites. Washington, DC: Pew Research Center's Hispanic Trends Project.

Luttrell, W. (2010). “Good enough" methods for life-story analysis. In W. Luttrell (Ed.), Qualitative educational research: Readings in reflexive (pp. 259-277). New York, NY: Routledge.

Martinez, M. (2012). Wealth, stereotypes, and issues of prestige: The college choice experience of Mexican American students within their community context. Journal of Hispanic Higher Education, 11(1), 67-81. doi:10.1177/ 1538192711428992

Martinez, M., Cortez, L., \& Saenz, V. (2013). Latino parents' perceptions of the role of schools in college readiness. Journal of Latinos and Education, 12(2), 108-130. doi:10.1080/15348431.2012.745402

Martinez, S., \& Cervera, Y. (2012). Fulfilling educational aspirations: Latino students' college information seeking patterns. Journal of Hispanic Higher Education, 11(4), 388-402. doi:10.1177/1538192711435560

Mason, P. L. (1997). Race, culture, and skill: Interracial wage differences among African Americans, Latinos, and whites. The Review of Black Political Economy, 25(3), 5-39. doi:10.1007/s12114-997-1001-5

Maxwell, J. A. (2005). Qualitative research design: An interactive approach (2nd. ed.). Thousand Oaks: Sage Publication.

McDonough, P., Antonio, A., \& Horvat, E. (1997, November). College choice as capital conversion and investment: A new model. Paper presented at the Annual Meeting of the Association for the Study of Higher Education, Memphis, TN. (ERIC Document Reproduction Service No. ED403785).

Milner, H. R. (2013). Analyzing poverty, learning, and teaching through a critical race theory lens. Review of Research in Education, 37(1), 1-53. doi:10.3102/0091732X12459720

Morrow, V., \& Richards, M. (1996). The ethics of social research with children: An overview. Children \& Society, 10(2), 90-105.

Musoba, G. D., \& Krichevskiy, D. (2013). Early coursework and college experience predictors of persistence at a Hispanic-Serving Institution. Journal of Hispanic Higher Education, 13(1), 48-62. doi:10.1177/1538192713513463

Nora, A. (2004). The role of habitus and cultural capital in choosing a college, transitioning from high school to higher education, and persisting in college among minority and nonminority students. Journal of Hispanic Higher Education, 3(2), 180-208. doi:10.1177/1538192704263189

Nuñez, A. M. (2009). Migrant students' college access: Emerging evidence from the migrant student leadership institute. Journal of Latinos and Education, 8(3), 181-198. doi:10.1080/15348430902888781

Parker, M. A., Segovia, E., \& Tap, B. (2016). Examining literature on Hispanic student achievement in the Southeastern United States and North Carolina. Journal of Hispanic Higher Education, 15(1), 55-68. doi:10.1177/ 1538192715585996

Patten, E. (2016, April 20). The nation's latino population defined by its youth. Pew Research Center: Washington, D.C. Retrieved from http://www.pewhispanic.org/2016/04/20/the-nations-latino-population-is-defined-by-its-youth/

Pendakur, V. (Ed.). (2016). Closing the opportunity gap: Identity-conscious strategies for retention and student success. Sterling, VA: Stylus Publishing, LLC.

Perez, P., \& McDonough, P. (2008). Understanding Latina and Latino college choice: A social capital and chain migration analysis. Journal of Hispanic Higher Education, 7(3), 1-17. doi:10.1177/1538192708317620

Perna, L. (2000). Differences in the decision to attend college among African Americans, Hispanics, and Whites. Journal of Higher Education, 71(2), 117-141. doi:10.2307/2649245 
Perna, L. (2006). Understanding the relationship between information about college prices and financial aid and students' college-related behaviors. American Behavioral Scientist, 49(12), 1620-1635. doi:10.1177/0002764206289144

Perna, L. W., Rowan-Kenyon, H., Bell, A., Thomas, S. L., \& Li, C. (2008). A typology of federal and state programs designed to promote college enrollment. The Journal of Higher Education, 79(3), 243-267. doi:10.1080/ 00221546.2008 .11772098

Pew Research Center. (2009). Between two worlds: How young Latinos come of age in America. Retrieved from http:// www.pewhispanic.org/2009/12/11/vi-education-the-gap-between-expectations-and-achievement/

Poindexter, C. (2002). Meaning from methods: Re-presenting narratives of an HIV-affected caregiver. Qualitative Social Work, 1(1), 59-78. doi:10.1177/147332500200100105

Poindexter, C. (2003). The ubiquity of ambiguity in research interviewing. Qualitative Social Work, 2(4), 383-409. doi: $10.1177 / 1473325003024002$

Riessman, C., \& Quinney, L. (2005). Narrative in social work: A critical review. Qualitative Social Work, 4(4), $391-412$. doi:10.1177/1473325005058643

Roderick, M., Nagaoka, J., \& Coca, V. (2009). College readiness for all: The challenge for urban high schools. The Future of Children, 19(1), 185-210.

Rodriguez, E., Rhodes, K., \& Aguirre, G. (2015). Intervention for high school Latino students in preparing for college: Steps for consideration. Journal of Hispanic Higher Education, 14(3), 207-222. doi:10.1177/1538192714551369

Rodriguez, J. M., \& Arrellano, L. (2016). The impact of high-stakes testing on Latina/o students' college aspirations. Journal on Hispanic Higher Education, 15(2), 113-135. doi:10.1177/1538192715627192

Sanchez, L., Usinger, L., \& Thornton, B. (2015). Predictive variables of success for Latino enrollment in higher education. Journal of Latinos and Education, 14(3), 188-201. doi:10.1080/15348431.2014.973565

St John, E. P., Musoba, G. D., \& Simmons, A. B. (2003). Keeping the promise: The impact of Indiana's twenty-first century scholars program. Review of Higher Education, 27(1), 103-123. doi:10.1353/rhe.2003.0042

St. John, E. (2002). The access challenge: Rethinking the causes of the new inequality [Policy Issue Report 2002 - 01]. Bloomington: Indiana Education Policy Center.

St. John, E. (2006). Contending with financial inequality: Rethinking the contributions of qualitative research to the policy discourse on college access. American Behavioral Scientist, 49(12), 1604-1619. doi:10.1177/0002764206289135

St. John, E., Daun-Barnett, N., \& Moronski-Chapman, K. (2013). Public policy and higher education: Reframing strategies for preparation, access, and college success. New York, NY: Taylor \& Francis.

St. John, E., \& Musoba, G. (2011). Pathways to academic success: Expanding opportunity for underrepresented students. New York, NY: Routledge.

St. John, E. P. S., Hu, S., \& Fisher, A. S. (2011). Breaking through the access barrier: How academic capital formation can improve policy in higher education. New York, NY: Routledge.

Syed, M., Azmitia, M., \& Cooper, C. R. (2011). Identity and academic success among underrepresented ethnic minorities: An interdisciplinary review and integration. Journal of Social Issues, 67(3), 442-468. doi:10.1111/ josi.2011.67.issue-3

Tienda, M. (2006). Harnessing diversity in higher education: Lessons from Texas. In M. Devlin (Ed.), Ford policy forum, 2006: Exploring the economics of higher education (pp. 7-14). Washington, DC: NACUBO and the Forum for the Future of Higher Education.

Tillman, L. C. (2002). Culturally sensitive research approaches: An African-American perspective. Educational Researcher, 31(9), 3-12. doi:10.3102/0013189X031009003

U.S. Census Bureau. (2014). National characteristics: Vintage 2014. Retrieved from http://www.census.gov/popest/data/ national/asrh/2014/index.html

Valdez, J. (2008). Shaping the educational decisions of Mexican immigrant high school students. American Educational Research Journal, 45, 834-860. doi:10.3102/0002831208320244 